\title{
A Cristandade medieval entre o mito e a utopia
}

\section{Francisco José Silva Gomes}

este ensaio apresentaremos três temas para reflexão: em primeiro lugar
discutiremos a hipótese sobre o caráter eminentemente religioso da ideologia na Cristandade medieval; em seguida, ressaltaremos o papel da reforma "gregoriana” nos séculos XI e XII para a reestruturação desta Cristandade; e, por último, analisaremos mais detidamente a relação particular que os reformadores "gregorianos" articularam com a temporalidade enquanto categoria antropológica.

Entendemos por Cristandade um sistema de relações da Igreja e do Estado (ou qualquer outra forma de poder político) numa determinada sociedade e cultura. Na história do cristianismo, o sistema iniciou-se por ocasião da Pax Ecclesiae em 313 e deu origem à primeira modalidade de Cristandade dita "constantiniana" a qual se apresenta como um sistema único de poder e legitimação da Igreja e do Império tardoromano. ${ }^{1}$

As características gerais desta modalidade "constantiniana" de Cristandade são, entre outras, o cristianismo apresentar-se como uma religião de Estado, obrigatória portanto para todos os súditos; a relação particular da Igreja e do Estado dar-se num regime de união; a religião cristã tender a manifestar-se como uma religião de unanimidade, multifuncional e polivalente; o código religioso cristão, considerado como o único oficial, ser todavia diferentemente apropriado pelos vários grupos sociais, pelos letrados e iletrados, pelo clero e leigos. ${ }^{2}$

A Cristandade medieval ocidental é, em certa medida, a continuadora da Cristandade antiga, a do "Império Cristão" dos séculos IV e V. No contexto medieval, acentuou-se muito mais a situação de unanimidade e conformismo, obtida por um consenso social homogeneizador e normatizador, consenso este favorecido pela constituição progressiva de uma vasta rede paroquial e clerical. As instituiçôes todas tendiam, pois, a apresentar um caráter sacral e oficialmente cristão. ${ }^{3}$ 
A religião na Cristandade medieval tendia a fornecer a explicação e justificação das relações sociais no plano das representações e discursos, e a constituir o sistema das práticas e comportamentos coletivos destinados a reproduzir estas relações sociais. A religião também podia servir a reduzir os antagonismos nas relações entre os homens e a natureza, superando-as no campo simbólico. Tratava-se propriamente do papel ideológico da religião. ${ }^{4}$

Ora, a ideologia era, na Cristandade medieval, eminentemente religio$s a$, sacralizadora do poder, das autoridades, da ordem vigente (Ordo). As relações senhoriais e servis, sobretudo a partir dos séculos X-XI, eram tão arbitrárias que só podiam justificar-se apelando para uma sanção meta-social. As relações sociais apareciam na consciência dos agentes sociais como "naturais" e necessárias, naturalizadas portanto. As práticas sociais delas decorrentes eram percebidas não como uma imposição, mas como atos voluntários ou como deveres morais e religiosos.

Como a ordem natural e a ordem social eram consideradas equivalentes e garantidas pela ordem divina (sobrenatural), as relaçóes sociais eram simultaneamente naturalizadas e sobrenaturalizadas. É a religião na sua função integradora, de coesão social pela qual os homens encontram compensação para a sua situação presente, na esperança de uma salvação futura. ${ }^{5}$

No entanto, toda a quebra do equilíbrio destas relações sociais por alguma forma intolerável de arbítrio, toda a contradição, tornada insustentável, entre a ideologia religiosa e a situação vivida, forjavam formas de protesto social e geravam movimentos de contra-legitimação que se expressavam igualmente em termos religiosos. É a religião na sua função de protesto social pela qual a esperança, que apresenta todavia um caráter ambivalente, constitui-se como fonte de utopias com conotações religiosas, podendo ser fonte de resignação e conformismo. ${ }^{6}$

À ordem perturbada por um tal arbítrio foram propostas geralmente, na Cristandade medieval, três soluções, a saber, uma projeção no passado tentando restabelecer a antiga ordem; uma projeção no futuro criando assim quer uma utopia em termos puramente pós-históricos, quer uma utopia em termos simultaneamente infra e pós-históricos. Nos três caos, a ordem era sempre pensada em seus fundamentos religiosos. 
Nas duas primeiras soluções, desejava-se a manutenção da ordem; na terceira solução, podia-se chegar a pensar a sua subversão. A religião atuava ora como entrave às transformações sociais, ora como estímulo a um projeto de uma nova ordem. Os movimentos medievais de protesto social produziram críticas à Igreja estabelecida, correntes religiosas consideradas heréticas, movimentos messiânicos e milenaristas. ${ }^{7}$

A propósito do messianismo, convém lembrar que a Cristandade medieval herdou o paradigma bíblico de messianismo. O povo de Israel vê-se como povo da promessa e da espera, vivendo numa contínua abertura para o futuro. Esta abertura nasce da relação do "povo eleito" com o seu Deus, o qual põe o presente sempre em discussão. Do encontro tenso do presente com a espera (futuro) nasce a esperança no Deus das promessas.

$\mathrm{O}$ anseio pela realização das sucessivas promessas de Deus na história do povo de Israel deu origem a diferentes formas de espera messiânica: a da sua realização num futuro iminente e intra-histórico (o messianismo profético); a sua relação com o poder (messianismo régio) ou com o culto (messianismo sacerdotal); a sua formulação em termos de uma utopia póshistórica (messianismo apocalíptico). O cristianismo radicalizou todas estas formas de espera messiânica afirmando querigma (anúncio) que Jesus, Cristo e Senhor, realizou todas estas formas de messianismo. ${ }^{8}$

Voltando à Cristandade medieval, sabemos que nela predominou, em geral, a tutela do clero. Não todavia durante os séculos IX e X, quando a tutela dos leigos sobre as instituiçōes eclesiais a levou à sua feudalização, o que provocou a partir do século XI, o grito dos reformadores, sobretudo eclesiásticos: libertas Ecclesiae. Ocorreu então a reforma "gregoriana" que operou a síntese de uma reforma na e da Igreja, de uma reforma "na cabeça e nos membros".

Tratava-se de lutar contra os pecados e misérias dos cristãos por meio de uma renovatio e reformatio dos homens, num processo de conformação com o Cristo, numa conversatio cristoforme. Era uma reforma na Igreja. Mas era opinião corrente entre os "gregorianos" que a reforma na Igreja só se viabilizaria com mudanças urgentes e necessárias nas instituições da Igreja e da Cristandade. Era uma reforma da Igreja. Com a reforma gregoriana, a dimensão da reforma $d a$ Igreja passou a predominar, sendo até considera- 
da como condição sine qua non para haver reforma na Igreja. Para tanto tornava-se imperativa a emancipação da tutela dos leigos. A reforma gregoriana tornou-se modelo paradigmático de reforma na Igreja Católica. ${ }^{9}$

Os reformadores gregorianos tinham um projeto de reestruturação da Cristandade. Por isso, distinguiam até a oposição dois poderes na Cristandade, sem colocar contudo o sistema em questão, já que mantinham a idéia de um único Orbis christianus. A unidade da Cristandade continuava intocada, mas a Igreja socializava com maior densidade o sistema religioso e o poder espiritual - a Sancta Ecclesia, e dessacralizava parcialmente a esfera do poder temporal - o Sacrum Imperium. Estavam, pois, reunidas as condiçôes de possibilidade para a emergência de um discurso autônomo tanto sobre o Estado quanto sobre a Igreja (eclesiologia). ${ }^{10}$

A escolástica e o direito canônico foram elaborando uma eclesiologia em torno de algumas idéias-força: a autocompreensão da Igreja como potestas (o poder espiritual); a subordinação do poder temporal ao poder espiritual numa clara tentativa hierocrática do poder clerical e do papado, subordinação que estava respaldada em dois processos concomitantes e imbricados de clericalização e romanização. O primeiro constituía-se no reforço do já tradicional monopólio clerical sobre o poder religioso e as instituições eclesiais e eclesiásticas, demarcando com maior ênfase a fronteira entre o clero e os leigos, usando para tanto a oposição entre o celibato e o casamento. Já o segundo processo preconizava o monopólio jurisdicional da Igreja romana e do papado sobre as Igrejas locais. ${ }^{11}$

Neste projeto da Igreja gregoriana tratava-se não somente de excluir os leigos da gestão das instituições eclesiais e eclesiátiscas, de destituí-los do poder religioso, mas também de os tutelar na direção da Cristandade. As relações entre o Sacerdotium e o Imperium, entre os dois poderes que se consideravam de direito universais, eram explicadas pelos escolásticos segundo duas correntes: a corrente dualista tout court, que insistia na distinção dos "dois gládios" numa simples relação de simetria, predominou no século XII; a corrente dualista e hierocrática, que insitia na relação assimétrica, foi dominante no século XIII. ${ }^{12}$

É tempo de analisar a reforma gregoriana na sua relação particular, no nível das representaçôes e discursos, com a temporalidade. Neste ponto 
em particular, a reforma elaborou o seu projeto de reestruturação da Cristandade num duplo plano, imbricado muito embora: o da projeção num passado idealizado (no nível do mito) e o da projeção num futuro idealizado (no nível da utopia), segundo um modelo retropectivo e prospectivo respectivamente.

No primeiro caso, o passado idealizado era o cristianismo apostólico (no ideal da vita vere apostolica dos séculos XII-XIII), e a Cristandade antiga (o ideal do Império cristão dos séculos IV e V) colocados ambos num passado imemorial, como realizaçóes perfeitas do cristianismo a serem retomadas pela reforma. Era uma forma de idealização do passado que conjugava mito e utopia. No segundo caso, o futuro idealizado era o de uma sociedade perfeita em termos puramente pós-históricos (o ideal da Jerusalém celeste, da Civitas Dei celeste). Era uma forma de idealização do futuro que conjugava escatologia e utopia. O projeto da Igreja gregoriana enlaçava-se, pois, com um passado mítico e se abria para um futuro escatológico, ambos igualmente utópicos. ${ }^{13}$

Entre o mito e a utopia, a Igreja estava inteiramente voltada para a tarefa de contribuir, na sua esfera própria, para o grande desígnio de fazer prevalecer a ordem na sociedade/Cristandade única com seus dois poderes - o Papado e o Império.

Esta tensão temporal da Igreja gregoriana encontra sua explicação em grande parte na maneira como o cristianismo encara a temporalidade enquanto categoria antropológica. A Igreja se entende como peregrinante (viator) em marcha para a casa do Pai, a pátria celeste, na espera do Reino de Deus plenamente consumado. A Igreja vive assim o tempo presente como um tempo da decisão e da oportunidade (como um kairós), como um tempo intermediário entre o tempo do dom já confirmado no passado e o tempo do cumprimento no futuro de uma promessa que ainda não aconteceu plenamente. O tempo da Igreja é assim o de uma tensão escatológica entre o "já” do dom ofertado e o "ainda-não” da promessa não plenamente realizada, entre a origem e o destino, entre o provisório e o definitivo, entre o tempo que se chama hoje e a eternidade. ${ }^{14}$

Para a Igreja, o Evangelho anuncia o escathon, a realidade última da história, como já realizado e revelado na vida, morte e ressurreição de Je- 
sus. Os Evangelhos não apresentam contudo o presente e o futuro como alternativos. A escatologia neles está relacionada com o Reino de Deus que já se realizou em Jesus - posição da escatologia dita realizada ou inaugurada, mas que ainda-não se realizou plenamente mas tão-somente de maneira incoativa - posição da escatologia dita futura ou conseqüente. A dialética do "já" e do "ainda-não" da escatologia neotestamentária realiza a síntese das duas posiçóes. ${ }^{15}$

A escatologia cristã relaciona-se, por sua vez, com a categoria bíblica de "História da Salvação". Na tradição semítica e veterotestamentária, a experiência de Deus feita por Israel não está tanto nos fenômenos cósmicos, nem na natureza divina hierofânica, mas antes no comprometimento de Deus com o acontecer do Povo eleito. ${ }^{16}$ A proximidade do Deus que vem, a expectativa do seu advento alimenta a esperança de Israel. Assim sendo, a narrativa das mirabilia Dei realizadas na história do seu povo (no passado) alimenta-lhe a esperança de outras intervenções de Deus (no futuro). Duas categorias fundamentam este modo discurso histórico-salvífico na Bíblia, a saber: a memória e a promessa.

Com a categoria de "memória” são confessados juntos na Bíblia a história dos atos fundantes do povo imbricada com o seu significado teológico. Pode haver, neste nível, uma interferência do discurso mítico, dandose assim quer uma historicização do mito, quer uma mitização da história.

Com a categoria de "promessa" surge o tempo das iniciativas de Deus e da profecia. Esta última fala de acontecimentos iminentes num futuro intra-histórico e aplica-lhes uma perspectiva histórico-salvífica que anula parcialmente a história passada, a tradição. Pode haver, neste nível, uma interferência do discurso escatológico. Enquanto a profecia anuncia acontecimentos iminentes, a escatologia anuncia uma nova ordem vinda de fora da história e consumada no após da história. Por vezes, esta virada do fim da história é apresentada precedida de uma catástrofe cósmica: trata-se da apocalíptica. ${ }^{17}$

A escatologia cristã pode relacionar-se ainda no discurso mítico, entendido como uma narrativa das origens, como um discurso cuja função é instauradora. Nesta relação entre a escatologia e o mito não se insiste tanto na antiguidade da criação primordial quanto no novum de qualquer cria- 
ção. Deste modo o mito pode tornar-se não apenas um mito de fundação do passado, mas o mito de toda a fundação no futuro. Por sua exemplaridade, o mito torna-se o modelo de toda a criação que há-de vir no futuro. Cada recriação recapitula a criação primordial e todos os começos são, pois, recomeços, conjugando-se o mito do começo com o do fim último, a protologia com a escatologia.

Resumindo, a escatologia cristã, na Bíblia, relaciona-se com as categorias de "memória" e "promessa" do discurso histórico-salvífico, com a profecia e com discurso mítico. ${ }^{18}$

No período do judaísmo tardio e do cristianismo nascente (século II a.C. - II d.C.), o discurso escatológico chegou a dominar todas as outras formas de discurso bíblico. Encontramos neste discurso ora o tempo cíclico, ora o tempo irreversível, ora ainda uma combinação de ambos.

A escatologia apresenta-se então segundo duas vertentes. Uma escatologia de corte apocalíptico buscava os seus modelos nos mitos, acentuava o tempo cíclico e a idéia de palingenesia, mas perdia muito a sua capacidade de falar sobre os fins últimos. A escatologia de corte profético referia-se não somente a esses fins últimos (escatha), mas também ao último de todas as realidades (escathon), privilegiando o tempo irreversível. $\mathrm{O}$ cristianismo pregava o evento escatológico por excelência, plenitude e pleroma da História: Jesus o Cristo (Escathos). ${ }^{19}$

Com a situação de Cristandade a partir do século IV, acentuou-se uma perda da carga profética e escatológica do querigma cristão. O sentimento de estranheza do cristão com relação ao mundo e a força crítica da esperança escatológica foram atenuando-se. Houve, pois, uma certa instalação no saeculum, dando-se um processo de desescatologização que não significa uma perda total da dimensão escatológica na Igreja, mas uma diminuição do clima de iminente expectativa do final dos tempos.

Dava-se no discurso cristão um relativo rebaixamento do seu universalismo a um messianismo mais particularista. A Igreja tendia a fixar a sua catolicidade, identificando-a parcialmente com o Império Romano, com a romanitas. $\mathrm{O}$ universalismo cristão tendia, pois, a identificar-se com o sistema, restringindo o seu horizonte ao Império romano. Esta quase-identificação tendeu a esbater a fronteira e tensão Igreja e mundo. 
Dava-se no entanto um outro processo concomitante de quase-identificação: da Igreja, novo "povo eleito" de Deus, com o Reino de Deus. A auto-compreensão da Igreja tomava um colorido "monofisita", numa analogia com a questão cristológica contemporânea. Desta maneira, a Igreja acabava hipostasiada em Deus, colocada na sua eternidade, e passava a atribuir-se o monopólio da salvação, da graça, de Deus mesmo. Há assim uma relação entre esta visão eclesiológica e um messianismo particularista em termos soteriológicos. É, pois, uma eclesiologia que operava uma leitura reducionista do aforismo teológico Extra Ecclesiam nulla salus, e que justificava o establishment eclesiástico com a sua visão triunfalista.

As relações estreitas entre cristologia, eclesiologia e soteriologia foram possibilitadas pelo processo de desescatologização, assinalado acima, na pregação do Reino de Deus, sustentado por um processo concomitante de de-historicização e helenização do querigma. ${ }^{20}$

No cristianismo antigo e medieval operou-se uma lenta bifurcação da escatologia, levando à distinção entre a escatologia individual e a escatologia coletiva. A esperança escatológica era o horizonte das comunidades apostólicas e dos mártires dos três primeiros séculos, permanecendo, no contexto da Cristandade, o horizonte de certos grupos em seu entusiasmo apocalíptico e no seu otimismo milenarista. ${ }^{21}$ Já o pensamento oficial e a teologia erudita distanciaram-se da tendência quiliástica, marginalizandoa e elaborando outro tipo de discurso escatológico no qual o millenium era dissolvido numa concepção mais pessimista e penitencial dos fins últimos.

A bifurcação da escatologia cristã consumou-se com a teologia agostiniana, mantendo o cristianismo numa permanente tensão entre instituição e inspiração, entre poder e carisma. Agostinho refutou o milenarismo e a escatologia iminente, rejeitando a possibilidade da identificação de um reino visível de Cristo na terra antes do Juízo Final e falando antes de uma presença invisível do Reino de Deus na Igreja. Nesta escatologia que se tornou oficial na Cristandade medieval, o futuro prometido era reconhecido como já presente no culto, na proclamação da Palavra de Deus, nos sacramentos, na Igreja. Dava-se deste modo uma quase identificação do Reino de Deus com a Igreja numa espécie de "êxtase" da realização no presente do futuro prometido. Era como que um "mito" do presente. 
Este processo de desescatologização na teologia oficial entroncou com uma escatologia de corte grego que acentuava a problemática da alma como substância espiritual, imortal, eterna, problemática esta reforçada na sua vertente neoplatônica. Foram, por isso, os Padres alexandrinos, antes de Agostinho, os que mais orientaram a escatologia oficial para a temática da imortalidade da alma, provocando assim uma virada interiorizante, espiritualizante e individualizante da salvação cristã. Orígenes já concedia aos justos a bem-aventurança desde separação da alma do corpo. Esta corrente escatológica foi consagrada dogmaticamente pela constituição Benedictas Deus de Bento XII em 1336.

No final da Idade Média consumava-se, na pastoral e na teologia, a ruptura e oposição entre a escatologia individual e a coletiva, ficando esta reduzida a um horizonte esfumado de futuro imprevisível. Estava sendo elaborado o futuro tratado tridentino dos Novíssimos.

A escatologia oficial deste tratado teológico estava mais voltada para as relações dos homens com o Além. Nele as questões eram formuladas a partir da consciência da fraqueza do homem alimentada pelo medo e a culpabilização; revelavam a preocupação pelo destino eterno da alma, pela salvação; configuravam a tentativa de assegurar já aqui na terra, com obras meritórias, a vida futura. Estas questóes tornaram-se a base de todo o esforço de "cristianização" na pastoral do final da Idade Média e na tridentina. ${ }^{22}$

Esta escatologia oficial dispensava de certa maneira os cristãos de se preocuparem com utopias intra-históricas. A Civitas Dei, a pátria verdadeira era a celeste. Historicamente na Cristandade medieval, muitas utopias refletem muito mais um desejo de volta às origens, ao Paraíso, do que a aspiração por uma nova sociedade. Era, pois, uma concepção de utopia "arcaica" vinculada ao mito, concepção de uma sociedade tradicional preocupada em manter estruturas imutáveis. Era uma utopia-fuga de um presente sofrido para a tranqüilidade uterina e protegida das origens. Foi a visão de utopia de certos movimento milenaristas e de certos pensadores eruditos.

Cremos ter mostrado que, entre o Mito e a Utopia, os reformadores gregorianos tentaram criar, por vezes sem muito êxito, uma fronteira entre uma escatologia oficial e uma escatologia apocalíptica e/ou milenarista com o desígnio precípuo de fazer prevalecer a ordem na sociedade/Cristandade. 


\section{Notas}

${ }^{1}$ Gomes, Francisco José. O Sistema da Cristandade Colonial. Dissertação de Mestrado. Niterói: UFF, 1979, pp. 86-162; . Le projet de néo-chrétienté dans le diocèse de Rio de Janeiro de 1869 à 1915. Tese de Doutorado. Toulouse: UTM, 1991, pp. 25-32. ${ }^{2}$ Idem; . A Igreja e o poder: representações e discursos. In Ribeiro, Maria Eurydice. A vida na Idade Média. Brasília: EdUnB, 1997. pp. 33-37.

${ }^{3}$ Idem. p. 44.

${ }^{4}$ Houtart, François. Religião e modos de produção pré-capitalista. São Paulo: Paulinas, 1982. ${ }^{5}$ Idem. pp. 243-249.

${ }^{6}$ Idem, pp. 23-29; Furter, Pierre. A dialética da esperança. Rio de Janeiro: Paz e Terra, 1974. pp. 77-124.

${ }^{7}$ Le Goff, Jacques. (Org.) Héresies et société dans l'Europe pré-industrielle (11e-18e siècles). Paris: La Haye: Mouton, 1968. pp. 121-138 e 209-218.

${ }^{8}$ Forte, Bruno. Jesus de Nazaré. História de Deus, Deus da História. Ensaio de uma cristologia como história. São Paulo: Paulinas, 1985. pp. 65-86; Grelot, Pierre. A esperança judaica no tempo de Jesus. São Paulo: Loyola, 1996.

${ }^{9}$ Gomes, Francisco José. Op.cit. pp. 48-50.

${ }^{10}$ Congar, Yves. L'Eglise. De Saint Augustin à l'époque moderne. Paris: Cerf, 1970. pp. 89122; Cf. Vauchez, André. (Org.), Apogée de la Papauté et expansion de la Chrétienté (10541274) in Mayeur, Jean-Marie et al. (Org.) Histoire du Chritianisme. Paris: Desclée, 1993. tome $\mathrm{V}$.

${ }^{11}$ Congar, Yves. Op. cit. pp. 145-155;

Igreja e Papado. Perspectivas históricas. São Paulo: Loyola, 1997. pp. 11-32 e 103-126; Gomes, Francisco José. Op.cit. pp. 51-52.

${ }^{12}$ Congar, YvesL 'Eglise. De Saint Augustin à l'époque moderne. Paris: Cerf, 1970. pp. 142145 e 176-198; Igreja e Papado. Perspectivas históricas. São Paulo: Loyola, 1997. pp. 127-206; GOMES, Francisco José. Op.cit. p. 52.

${ }^{13}$ Para o conceito de utopia ver. Mannheim, Karl. Ideologia e utopia. Rio de Janeiro. Zahar, 1968; Freitas, Manuel da Costa. Utopia. In Logos. Enciclopédia luso-brasileira de Filosofia. Lisboa: Verbo, 1992. Vol. 5, pp. 365-371; Miller, David et al. (Org.) Dictionnaire de la pensée politique. Hommes et Idées. Paris: Hatier, 1989. pp. 813-824.

${ }^{14}$ Libanio, João Batista, Bingemer, Maria Clara. Escatologia cristã. Petrópolis: Vozes, 1985. pp. 74-145.

${ }^{15}$ Cullmann, Oscar. Le salut dans l'histoire. Neuchâtel: Delachaux, 1966. pp. 30-40.

${ }^{16}$ Läpple, Alfred. As origens da Bíblia. Petrópolis: Vozes, 1973. pp. 70-80.

${ }^{17}$ Cf. Russell, D. S. Desvelamento divino. Uma introdução à apocalíptica judaica. São Paulo: Paulinas, 1997.

${ }^{18}$ Ricoeur, Paul. Mito. A interpretação filosófica. In Ricoeur, Paul et al. (Org.) Grécia e mito. Lisboa: Gradiva, 1988. pp. 9-40. 
${ }^{19}$ Libanio, João Batista, Gingemer, Maria Clara. Op. cit. pp. 19-30 e 74.

${ }^{20}$ Forte, Bruno. Op.cit. pp. 136-162; Gomes, Francisco José. Op.cit. pp. 40-41.

${ }^{21}$ Carozzi, Claude, Taviani-Carozzi, Huguette (Orgs.). La fin des temps. Terreurs et propheties au Moyen Age. Paris: Stock, 1982. pp. 171-233; Cohn, Norman. Na senda do milênio. Milenaristas, revolucionários, anarquistas e misticos da Idade Média. Lisboa: Presença, 1981.

${ }^{22}$ Libanio, João Batista. e Bingemer, Maria Clara. Op. cit. pp. 57-73.

\section{Resumo}

Apresentaremos neste ensaio três temas para a reflexão: em primeiro lugar, discutiremos a hipótese sobre o caráter eminentemente religioso da ideologia na cristandade medieval. Em seguida, ressaltaremos o papel da "reforma gregoriana" no século XI para a reestruturação desta nova cristandade; por último analisaremos a reação particular que os "reformadores gregorianos" criaram com a temporalidade enquanto categoria antropológica. Cremos que entre o mito e a utopia, os "reformadores gregorianos" tentaram criar, por vezes sem muito êxito, uma fronteira entre uma escatologia oficial e uma escatologia apocalíptica elou milenarista, com o designio sobretudo de fazer prevalecer a ordem na sociedadelcristandade.

\section{Abstract}

We will present in this essay three themes for reflection: first, the eminently religious character of ideology in medieval Christendom; second. the role of the "Gregorian Reformation" of the $11^{\text {th }}$ century in the restructuring of this new Christendom; and last, the particular reaction created by the "Gregorian reformers" with temporality (meant as anthropological category). We believe that between myth and utopia, the "Gregorian reformers" tried to create, sometimes without being successful, a border between official and apocalyptic or millenarian eschatology, intending to promote order in society/Christendom. 